\title{
THE KEY TO EFFECTIVE ORGANIZATIONAL PERFORMANCE MANAGEMENT LIES AT THE INTERSECTION OF PARADOX THEORY AND STAKEHOLDER THEORY
}

\author{
Jonathan Pinto \\ Imperial College Business School \\ 294 Tanaka Building \\ South Kensington \\ London SW7 2AZ \\ Tel: 0207-594-8543 \\ Email: j.pinto@imperial.ac.uk
}

January $4^{\text {th }}, 2019$ 


\title{
THE KEY TO EFFECTIVE ORGANIZATIONAL PERFORMANCE MANAGEMENT LIES AT THE INTERSECTION OF PARADOX THEORY AND STAKEHOLDER THEORY
}

\begin{abstract}
One of the fundamental and recurring issues in performance management is the adoption of a simplistic, short-term, narrow, metrics-oriented approach which often results in unintended negative outcomes, some of which could be disastrous. This paper makes the case that the key to preventing this syndrome lies at the intersection of paradox and stakeholder theories. Both theories encourage a more complex, long-term, holistic, balanced approach to management. Stakeholder theory focuses on addressing the many (sometimes conflicting) goals of multiple stakeholders, and paradox theory provides insights into how this challenging task (i.e., of simultaneously addressing multiple conflicting priorities) can be accomplished. Thus, the former provides the 'what', and the latter, the 'how', of effective organizational performance management. Accordingly, the literature at the intersection of both theories (comprising 69 scholarly outputs), was reviewed, and in so doing, identified seven domain areas and 21 constructs, all of which implicitly deal with either performance management or its communication, thereby lending support to this paper's thesis. The implications of this review for both theory and practice, including the role of paradoxical cognitive mechanisms, is discussed.
\end{abstract}

Key words: performance management, paradox theory, stakeholder theory 
Effective organizational performance management has proved to be one of the most enduring management challenges. Organizations tend to apply the well-established management practice of management by objectives (Drucker 1954; Odiorne 1965) which is based on two commonsensical premises, i.e., "what gets measured is what matters" (Bevan and Hood 2006, p. 517) and "measuring outcomes leads to better outcomes" (Grizzle 2002, p. 363). And although these premises and their underlying intuitions are solid, managing by metrics could, and often does, lead to negative outcomes. The downside of focusing largely, if not exclusively, on a narrow set of short-term performance metrics (cf. targetology, Rouse 1993) is well-established in the management literature (e.g., Bevan and Hood 2006; Brownell and Hirst 1986; Smith 1993 and 1995). This downside includes unintended negative outcomes such as, mistakes (Brewer 2018), corruption (Ashforth and Anand 2003; Pinto et al. 2008), and gaming (Radnor 2008).

A recent example of these negative consequences is the resignation of the United Kingdom Home Secretary Amber Rudd on April $29^{\text {th }} 2018$ after an official memo was discovered which showed that she was aware of targets for the deportation of illegal immigrants even though she had earlier denied the existence of such targets in the British Parliament. On the same issue, even more recently, a Home Office asylum caseworker codenamed 'Alex' has claimed that because management were obsessed with unachievable 'stats', staff had to work so fast that their decisions to deport were a 'lottery' (i.e., more based on chance than on proper analysis) which may have resulted in innocent people being sent home to their deaths (Brewer 2018).

And though it is tempting to dismiss this as politics and bureaucracy as usual, metricsrelated pressures have also resulted in individual-level negative consequences in the supposedly more noble profession of academia. The pressures of the "publish or perish" (de Rond and Miller 2006; Miller et al. 2011) performance management model has resulted in an increase of unethical 
methods to achieve publishing targets. These unethical methods include plagiarism, data duplication, and statistical irregularities as in the case of Ulrich Lichtenthaler (Retraction Watch 2012, 2014) or even completely fabricating data like Diederik Stapel did (Bhattacharjee 2013). And when the key metric is not publications, it is grant income, and excessive focus on that too can be tragic. For example, in 2014, Stefan Grimm, professor of toxicology in the Faculty of Medicine at Imperial College London committed suicide because he could not cope with the pressure of (and perceived consequences of not) achieving his grant income target (Parr 2014).

And it is not just individuals who are impacted. The negative unintended consequences of an excessively metrics-oriented performance management are also felt at the organization- and economy-levels. For instance, incentive compensation and emphasis on short-term profits are among the causes of accounting scandals (Ball 2009) that have sometimes resulted in organizational deaths e.g., Arthur Andersen, Enron, Parmalat, and Satyam Computer Systems. Similarly, perverse incentives were among the structural causes of the 2008 financial crisis (Coval et al. 2009; Crotty 2009).

This begs the question - if the negative consequences of a narrow, excessively metricsoriented performance management system are well-known, and its antidote, i.e., a broader, more holistic and balanced-across-multiple-goals approach (e.g., Kaplan and Norton 1996; Dodd and Favaro 2006), is well-established - why do practitioners continue to make the same mistakes? There are two potential rationales. First, the perceived primacy of a single stakeholder (typically the shareholder) and consequent focus largely on the one (or few) metrics that matter to that stakeholder (typically, earnings or shareholder value). Second, the complexity (both cognitive and behavioral) of attempting to address multiple, sometimes conflicting priorities. The first rationale is consonant with the view advocated by scholars who claim it is logically impossible 
to maximize in more than one dimension, and social welfare is maximized when each firm maximizes its total value (cf. enlightened value maximization, Jensen 2001). And with regard to the second rationale (i.e., simultaneously trying to achieve positive results on two conflicting dimensions) Dodd and Favaro (2006, p. 70) put it best when they said, "if we chase two rabbits, both will escape."

These two rationales are addressed by stakeholder theory and paradox theory respectively. The first rationale, i.e., overfocus on one stakeholder, is counter to stakeholder theory which describes and advocates "simultaneously attention to the legitimate interests of all appropriate shareholders [emphasis added]" (Donaldson and Preston 1995, p. 67). The second rationale, i.e., the challenge of focusing and managing multiple, often conflicting priorities is addressed by paradox theory, which considers tensions or conflicts as inherent in organizational systems and seeks approaches to embrace their persistent nature (Smith and Tracey 2016, p. 456). Thus, stakeholder theory and paradox theory together address the performance management challenges faced by managers and leaders.

The two theories, have three key common features, which is where they intersect and guide effective performance management. Firstly, both theories deal with multiple elements or plurality. Paradox by definition needs to have two elements, and stakeholder refers to all (i.e., multiple) entities who can affect or are affected by the achievement of an organization's objectives (Freeman 1984). Secondly, both theories deal with conflict between or among these multiple elements, and this conflict may or may not be driven by scarcity. In paradox theory, the conflict is explicit, whereas it is usually implicit in stakeholder theory. Finally, both theories are about managing (and not eliminating) the conflict. Stakeholder theory advocates simultaneous attention to all legitimate interests, even if they are conflicting (Donaldson \& Preston, 1995), 
whereas paradox theory provides multiple approaches to managing persistent contradictions among conflicting elements. Thus, stakeholder theory provides guidance on the 'what' (i.e., simultaneously address multiple, often conflicting interests), and paradox theory provides guidance on the 'how' (i.e., how to simultaneously manage competing objectives). And since both theories are needed to address the challenge of effective organizational performance management, I reviewed papers at the intersection of both theories to see if they provided greater insight into this issue.

This article is organized as follows. In the next section, the two focal theories, i.e., paradox theory and stakeholder theory, are compared and contrasted, and their implications for performance management are discussed. After that the Methodology section describes the process followed to identify the 69 papers that are at the intersection of the two theories. The subsequent section presents the Analysis of the sample of 69 papers, and it is followed by the Findings section. Finally, in the Discussion section, the contribution of this paper is summarized and its implications for theory and research are delineated.

\section{Paradox Theory, Stakeholder Theory, and Performance Management}

The similarities and differences between paradox theory and stakeholder theory are summarized in Table 1. The focus of this paper, the area of intersection, is highlighted. Both theories are meta-theories, i.e., each has “an over-arching theoretical perspective” (Ritzer 1990, p. 3), implying that they are wide and general in scope, and both are managerial, in that they have relevance for practitioners. Hence, each theory and both together, conceivably encompass the field of performance management. Further, both theories embrace (rather than shy away from) complexity and the management of conflicting objectives or interests (as is the case with 
effective organizational performance management) by not eliminating the source of conflict, but

rather, attempting to balance them.

Table 1: Paradox Theory and Stakeholder Theory - Similarities and Differences

\begin{tabular}{|c|c|c|}
\hline Characteristic & Paradox Theory & Stakeholder Theory \\
\hline Key term definition & $\begin{array}{l}\text { Paradox: "Contradictory yet interrelated elements } \\
\text { (dualities) that exist simultaneously and persist } \\
\text { over time; such elements seem logical when } \\
\text { considered in isolation, but irrational, inconsistent, } \\
\text { and absurd when juxtaposed" (Smith \& Lewis 2011: } \\
\text { 387). }\end{array}$ & $\begin{array}{l}\text { Stakeholder: A member of the groups without } \\
\text { whose support the organization would cease to } \\
\text { exist (Freeman \& Reed 1983). Stakeholders: "Any } \\
\text { group or individual who can affect or is affected by } \\
\text { the achievement of the organization's objectives" } \\
\text { (Freeman 1984: 46). }\end{array}$ \\
\hline Roots/origins & Philosophy, psychology (Schad et al. 2016) & Management practice (Freeman \& McVea 2001) \\
\hline Theory description & $\begin{array}{l}\text { "Paradox theory considers tensions or conflicts as } \\
\text { inherent with organizational systems and seeks } \\
\text { approaches to embrace their persistent nature" } \\
\text { (Smith \& Tracey 2016: 456). }\end{array}$ & $\begin{array}{l}\text { Stakeholder theory describes and advocates } \\
\text { "simultaneous attention to the legitimate interests } \\
\text { of all appropriate stakeholders" (Donaldson \& } \\
\text { Preston, 1995: 67). }\end{array}$ \\
\hline Meta-theory? & Yes (Schad et al. 2016). & $\begin{array}{l}\text { Yes. Stakeholder theory can be unpacked into a } \\
\text { number of stakeholder theories, each of which has } \\
\text { a normative core (Freeman 1994). }\end{array}$ \\
\hline Level of analysis & $\begin{array}{l}\text { Applicable to all levels of analysis, but organization- } \\
\text { level predominantly (Schad et al. 2016) }\end{array}$ & $\begin{array}{l}\text { Organization-level necessarily, relationships } \\
\text { between firm and other entities (Parmar et al. } \\
\text { 2010) }\end{array}$ \\
\hline Descriptive? & No. & Yes. (Donaldson \& Preston 1995) \\
\hline Instrumental? & No. & Yes. (Donaldson \& Preston 1995) \\
\hline Normative? & No. & Yes. (Donaldson \& Preston 1995) \\
\hline Managerial? & Yes. (Hough et al. 2005; Smith et al. 2012) & Yes. (Donaldson \& Preston 1995; Hough et al. 2004)) \\
\hline \begin{tabular}{|l|} 
Relationship to complexity \\
\end{tabular} & Embrace it & Embrace it \\
\hline Plurality? & Yes (duality). & Yes (multiplicity). \\
\hline Concept of balance relevant? & Yes (Hannan 2014; Schad et al. 2016). & Yes \\
\hline Is conflict necessary? & $\begin{array}{l}\text { Necessary. Assumes that every organization } \\
\text { embeds conflicts, although such tensions may be } \\
\text { latent (Smith \& Tracey 2016: 460). }\end{array}$ & $\begin{array}{l}\text { Not necessary. Could arise from contradictory } \\
\text { demands/expectations of internal and external } \\
\text { stakeholders (Donaldson \& Preston 1995) }\end{array}$ \\
\hline Source of conflicts & $\begin{array}{l}\text { Are inherent in the organization, emerging through } \\
\text { the act of the organization or emerging through } \\
\text { relational dynamics or individual sensemaking } \\
\text { (Smith \& Tracey 2016: 457). }\end{array}$ & $\begin{array}{l}\text { Neverending task of balancing and integrating } \\
\text { multiple relationships and multiple objectives } \\
\text { (Freeman \& McVea, 2001: 194). }\end{array}$ \\
\hline Nature of conflicts & $\begin{array}{l}\text { Tensions are both contradictory (oppositional, } \\
\text { inconsistent, conflictual) and interdependent } \\
\text { (interrelated, synergistic, mutually constituted) } \\
\text { (Smith \& Tracey 2016: 457). }\end{array}$ & $\begin{array}{l}\text { Tensions could be both oppositional and } \\
\text { interdependent. }\end{array}$ \\
\hline Challenge of conflicts & $\begin{array}{l}\text { Competing demands persist over time, and cannot } \\
\text { be resolved, but if effectively engaged can foster } \\
\text { creativity, sustainability (Smith \& Tracey 2016: 457). }\end{array}$ & $\begin{array}{l}\text { Profound ideological and political challenges faced } \\
\text { by pluralistic institutions (Kraatz \& Block 2008). }\end{array}$ \\
\hline Responding to conflicts & $\begin{array}{l}\text { Paradoxes provoke dynamic interactions and } \\
\text { require ongoing, processual responses (Smith \& } \\
\text { Tracey 2016: 457). }\end{array}$ & $\begin{array}{l}\text { Adopting/extending a balanced scorecard approach } \\
\text { (Jamali 2008; Spiller 2000) }\end{array}$ \\
\hline
\end{tabular}

\section{Stakeholder Theory and Performance Management.}

The term 'stakeholder' with regard to an organization or corporation traces its origin to a

1983 internal memorandum at the Stanford Research Institute (Freeman and Reed 1983), and 
was shortly thereafter incorporated into 'stakeholder theory' (Freeman 1984). The word 'stakeholder' was an obvious play on the word 'stockholder' and this approach sought to broaden the concept of strategic management beyond its traditional economic roots by defining stakeholders as "any group or individual who can affect or is affected by the achievement of the organization's objectives" (Freeman 1984, p. 46).

Thus, stakeholder theory describes and advocates "simultaneously attention to the legitimate interests of all appropriate shareholders" (Donaldson and Preston 1995, p. 67). It focuses on three interconnected business problems, i.e., the problem of the ethics of capitalism, the problem of value creation and trade, and the problem of managerial mindset (Parmar et al. 2010). According to Minoja (2012, p. 67), it assumes that "the purpose of the firm is to create and distribute value to a plurality of stakeholders and that the achievement of this purpose depends on the cooperation and support of the stakeholders themselves." Stakeholder theory has been applied across a whole host of management disciplines, including, business ethics, corporate strategy, finance, accounting, management, and marketing (Parmar et al. 2010).

According to Goodpaster (1991), stakeholder theory inevitably gives rise to a paradox which he termed the stakeholder paradox. In his opinion, stakeholder theory dictates that managers have both a contractual duty to manage the firm in the interests of the stockholders and a moral duty to take other stakeholders into account (Freeman and McVea 2001), and since no person can serve two masters, it is a paradox. However, there continue to be staunch adherents to both sides of the debate that there is (Sternberg 1997; Jensen 2001), or is not (West 2006), a fundamental and inherently unworkable incompatibility between shareholder interests and other stakeholder interests (Hough et al. 2005). Having said that, some scholars (e.g. Vilanova et al. 
2009) take the view that the incompatibility, to the extent it exists, can be managed by applying paradox theory. And the current paper is consonant with this view.

Stakeholder theory was elaborated by Donaldson and Preston (1995) who delineated its four theses as follows: (1) descriptive (i.e., what the corporation is); (2) instrumental (i.e., the connection between stakeholder management and corporate performance); (3) normative (i.e., what managers or corporations should do); and (4) managerial (i.e., research that addresses the needs of practitioners). Further, they claimed that the normative aspect was the central core and the other three parts were subordinate to it (Parmar et al. 2010), which is consistent with the view taken in this paper. In this regard, I argue that paradox theory could be effectively harnessed by stakeholder theory to fulfill its core normative or ethical aspect by providing direction to leaders (the managerial aspect) about superior ways to manage stakeholders (the descriptive aspect) so as to achieve sustainable corporate performance (the instrumental aspect).

\section{Paradox Theory and Performance Management.}

Paradox, defined as "persistent contradiction between interdependent elements" (Schad et al. 2016, p. 10), is an age-old concept with its roots in ancient teachings across Eastern and Western thought, such as the Tao Te Ching and the Judeo-Christian Bible (Smith and Lewis 2011). The disparate work on paradoxes was pulled together by Smith and Lewis (2011) to develop a theory of paradox. Paradox theory explores how organizations respond to, and seek to manage, the tensions which arise when simultaneously pursuing competing objectives (Jarzabkowski et al. 2013; Lewis 2000; Smith and Lewis 2011). This is crucial with regard to performance management, as organizations have tended to selectively focus on a narrow set of objectives or metrics. Applying a paradox theory perspective would discourage managers and leaders from this approach and encourage them to embrace multiple, competing objectives. 
Smith and Lewis (2011, p. 384) refer to this aspect as performing paradoxes (one of four fundamental organizational paradoxes) which "stem from the plurality of stakeholders and result in competing strategies and goals". Thus, performing paradoxes by definition deal with managing performance and achieving multiple goals across multiple stakeholders.

Paradox theory is ideally suited for examining organizational tensions (McMullen and Bergman 2017). As Handy (1995) points out with regard to the paradox of organizations, firms have to reconcile what used to be opposites (e.g., planning versus flexibility, mass market yet niche) instead of choosing between them. And that is the essence of managing paradoxes or tensions, the both/and approach rather than the either/or approach (Cornforth 2004; Lewis 2000). Thus applying paradox theory to management practice would discourage the practice of "robbing Peter to pay Paul" (Hitchen 2007), for instance, by underpaying employees in order to boost profits and shareholder returns. Paradox theory would also help leaders address the problem, articulated by Dodd and Favaro (2006), of simultaneously making progress on both sides of three seemingly conflicting pairs of objectives. These pairs of objectives are: (1) profitability versus growth; (2) short-term versus long-term; and (3) the whole organization versus its parts.

Although paradox theory was originally conceptualized at the organization-level, it can be applied at various levels of analysis, including individual, team, organizational, interorganizational, and field levels (Ocasio and Radoynovska 2016; Schad et al. 2016). At the individual level, Miron-Spektor et al. (2018) demonstrated that a paradox mindset (i.e., the extent to which one is accepting of, and energized by, tensions) can help individuals improve inrole job performance and innovation. This finding implies that if all employees, not just senior management, could cultivate a paradox mindset the organization would embrace paradoxes, such 
as satisfying multiple stakeholders with varied and sometimes competing demands (Denis et al. 2012; Freeman 1984), thereby managing performance more holistically and effectively.

Also, a workforce that has internalized a paradox mindset would be able harness creativity and innovation to develop superior (rather than myopic and suboptimal) ways of dealing with performing paradoxes. In this regard, the serious play model (Beech et al. 2004; Gergen 1992; Pinto 2016), which is one of the more recent approaches to resolving paradoxes, is relevant. Its features include the following: both rationality and emotion; both conformity and challenge with regard to rules; words and gestures that have multiple meanings; and challenging normal boundaries through experimentation. This model encourages a playful and open-minded attitude which once again militates against a cynical, gaming, ends-justify-the-means, flawed approach to performance management.

\section{Both Focal Theories and Performance Management.}

Stakeholder theory is a firm-level theory whose central admonition is that managerial attention should be paid simultaneously to the legitimate needs of multiple entities (Phillips et al. 2003). This is easier said than done. The challenges of the latter are evident when attempting to address questions such as, "who (or what) are the stakeholders of the firm? And to whom (or what do) do managers pay attention?" (Mitchell et al. 1997, p. 853). But even if the answer to the first question is clear, dealing with the second question, i.e., the allocation of managerial attention across stakeholders is still cognitively challenging.

Mitchell et al. (1997) attempt to resolve this issue by developing a typology of seven types of stakeholders, i.e., dormant, discretionary, demanding, dominant, dangerous, dependent, and definitive, based on whether they possess one or more of three attributes, i.e., power, legitimacy, and urgency. The more attributes (of these three) that a stakeholder possesses, the greater would 
be their salience. But even by this logic, there would be multiple stakeholders with high or moderate salience competing for managerial attention. Further, in a dynamic world these relative saliences would keep changing, creating even greater cognitive complexity and challenge in managing stakeholders. Another approach, based on the attention-based view of the firm (Ocasio 1997) would be that the firm focuses its attention on some stakeholders and withdraw them from others based on the situation and a variety of contextual factors. However, this approach would not be consistent with the stakeholder theory principle of simultaneous attention to all stakeholders (Donaldson and Preston 1995).

This cognitive challenge is best addressed by paradox theory, which is essentially cognitive in nature. The stakeholder management challenge of balancing attention across multiple conflicting interests is merely a specific case of a paradox. And not just any paradox, but a fundamental organizational one, i.e., performing paradox (Smith and Lewis 2011). And paradox theory provides a variety of modes to work with organizational paradoxes, such as accepting the paradox and using it constructively, clarifying the levels of analysis, temporally separating the two levels, introducing new terms, or adopting a serious play approach (Beech et al. 2004; Gergen 1992; Poole and Van de Ven 1989). Further, the application of paradox theory to stakeholder management can foster creativity and sustainability (Smith and Tracey 2016) as is evident in exemplars like the Icehotel (Pinto 2016, 2017), and lead to organizational well-being.

However, if paradox theory is not harnessed to facilitate stakeholder management the result could be disastrous. There is every likelihood that firms would resolve the tensions by simply focusing on some or a few stakeholders and ignore other legitimate but less urgent or powerful stakeholder interests (Mitchell et al. 1997; Ocasio 1997) and this narrow, myopic, short-term approach to organizational performance management could typically backfire in the medium- to 
long-term and even lead to disasters like Enron (Heath and Norman 2004). Thus, both theories need to be harnessed and together (i.e., at their intersection) provide the key to effective organizational performance management.

\section{Methodology}

In keeping with the title of this special issue, i.e., 'paradoxes', the primary focal construct of this paper is 'paradox theory' (also sometimes referred to as 'paradox perspective', 'paradox lens', or 'paradox approach'). The secondary focal construct of this paper is 'stakeholder theory', (also sometimes referred to as the 'stakeholder model'). Since the review is at the intersection of these two theories, the search terms were always entered in combinations, i.e., one paradoxrelated term AND one stakeholder-related term, wherein at least one of the two is the focal theory. The initial searches were carried out on several academic databases including Business Source Premier and SCOPUS. Then, because academic databases may not include the most recent work or work that is not in article form (e.g., book chapters, working papers, dissertations) all the afore-mentioned searches were carried out in Google Scholar as well. All these searches cumulatively resulted in 248 distinct pieces of scholarly output.

Each of these outputs was then reviewed to check whether the focal constructs were substantively covered in their content, and if they were not, the particular piece was dropped. For instance, the searches identified several pieces whose only mention of 'stakeholder theory' or 'paradox perspective' was in the References section, because they were included in the title of a cited article, and were therefore dropped. Other dropped pieces included those whose style and content were lay audience-oriented, although respected practitioner-oriented academic journals, such as California Management Review, were included. And though Masters' degree dissertations were excluded, some highly relevant doctoral dissertations were included. From the 
large number of working papers and conference papers all but three (which substantively discussed both focal theories) were excluded. Finally, as relevant papers were identified, both forward and backward cited reference searches were conducted to identify other relevant papers.

In order to keep the paper bounded and to maintain focus and cohesion in the selected set of papers, terms that could be considered as synonymous with, or equivalent to, the focal terms, e.g., conflicting logics (Ebrahim et al. 2014) or competing institutional demands or logics (Pache and Santos 2010, 2013) or ambidexterity (Minoja 2012), and which may have even cited the focal constructs in their argumentation, were not included if they did not make explicit mention of 'paradox' or one of the paradox theory terms.

This methodology has resulted in a final selection of 69 papers that were included in the review. The papers that have been included in the review have been flagged in the References section of this paper by the addition of an asterix $(*)$ at the end of each of their respective citations. The characteristics of this sample are summarized in Table 2. The balanced subsample contains papers that substantively included both key terms, i.e., 'paradox theory' and 'stakeholder theory'. The other two subsamples contain papers that substantively included both the terms 'paradox' and 'stakeholder', along with the term 'paradox theory' for the paradoxoriented subsample and 'stakeholder theory' for the stakeholder-oriented subsample. The balanced subsample is the most reflective of a mutual dialogue between the two focal theories, whereas the other two subsamples are skewed toward one theory or the other.

Table 2: Characteristics of the sample of papers included in the review 


\begin{tabular}{|c|c|c|c|c|c|c|c|c|c|}
\hline$\#$ & Publication & Abb. & Imp. F. & AJG 2018 Field & AJG 2018 & Balanced & Paradox & Stakeholder & Total \\
\hline 1 & Academy of Management Review & AMR & 9.41 & General Management & 4* & & 2 & & 2 \\
\hline 2 & Academy of Management Journal & AMJ & 7.42 & General Management & 4* & & 3 & & 3 \\
\hline 3 & Organization Science & Org. Sci. & 2.69 & Organization Studies & 4* & & 1 & & 1 \\
\hline 4 & Journal of the Academy of Marketing Science & JAMS & 5.89 & Marketing & $4^{*}$ & 1 & & & 1 \\
\hline 5 & Public Administration Review & PAR & 3.47 & Public Sector \& Health Care & 4* & & 1 & & 1 \\
\hline 6 & Academy of Management Annals & AOM Ann. & 11.12 & General Management & 4 & 2 & & & 2 \\
\hline 7 & Academy of Management Learning \& Education & AMLE & 2.43 & Management Dev. \& Edu. & 4 & & 1 & & 1 \\
\hline 8 & Business Ethics Quarterly & BEQ & 1.74 & General Management & 4 & 1 & & & 1 \\
\hline 9 & Human Relations & Hum Rels & 2.62 & Organization Studies & 4 & 1 & 1 & & 2 \\
\hline 10 & Organization Studies & Org. Stud. & 3.11 & Organization Studies & 4 & & 1 & & 1 \\
\hline 11 & Strategic Entrepreneurship Journal & SEJ & 2.54 & Entrepreneurship \&SBM & 4 & & 1 & & 1 \\
\hline 12 & Journal of Product Innovation and Management & JPIM & 3.76 & Innovation & 4 & & 1 & & 1 \\
\hline 13 & Journal of Management Studies & JMS & 3.96 & General Management & 4 & & 1 & & 1 \\
\hline 14 & Journal of Business Ethics & $\mathrm{JBE}$ & 2.35 & General Management & 4 & 4 & 3 & 3 & 10 \\
\hline 15 & British Accounting Review & BAR & 2.14 & Accounting & 3 & & 1 & & 1 \\
\hline 16 & Business and Society & Bus\&Soc & 3.30 & General Management & 3 & & & 1 & 1 \\
\hline 17 & California Management Review & CMR & 2.94 & General Management & 3 & & & 1 & 1 \\
\hline 18 & International Journal of Human Resources Management & IJHRM & 1.65 & HRM \& ES & 3 & 1 & & & 1 \\
\hline 19 & Long Range Planning & LRP & 3.55 & Strategy & 3 & & 1 & & 1 \\
\hline 20 & Strategic Organization & Strat.Org. & 1.94 & Strategy & 3 & 1 & 1 & & 2 \\
\hline 21 & World Development & World Dev & 2.85 & Social Sciences & 3 & & & 1 & 1 \\
\hline 22 & Annals of Public and Cooperative Economics & AnnPCE & & Economics & 2 & & & 1 & 1 \\
\hline 23 & Journal of Applied Behavioral Science & JABS & 1.44 & Organization Studies & 2 & & 1 & & 1 \\
\hline 24 & Journal of Management Education & JMgt.Ed. & & Management Dev. \& Edu. & 2 & & 1 & & 1 \\
\hline 25 & Management Revue: Socio-economic Studies & Mgt.Rev. & & General Management & 2 & 1 & & & 1 \\
\hline 26 & Organization \& Environment & O\&E & 3.86 & Organization Studies & 2 & 1 & 1 & 1 & 3 \\
\hline 27 & Theoretical Economics Letters & Th.Eco.Let. & & Economics & 1 & 1 & & & 1 \\
\hline 28 & Academy of Management Discoveries & AOM Disc. & & N.A. & N.A. & & 1 & & 1 \\
\hline 29 & Africa Journal of Economics \& Mgt. Studies & AfrJEMS & & N.A. & N.A. & & & 1 & 1 \\
\hline 30 & Business and Society Review & B\&S Rev. & & N.A. & N.A. & 1 & & & 1 \\
\hline 31 & Current Opinions in Environmental Sustainability & COSust. & 3.95 & N.A. & N.A. & 1 & & & 1 \\
\hline 32 & Discourse \& Communication & $\mathrm{D} \& \mathrm{C}$ & 1.81 & N.A. & N.A. & & 1 & & 1 \\
\hline 33 & HRM \& Ergonomics & HRM\&Ergo & & N.A. & N.A. & 1 & & & 1 \\
\hline 34 & Journal of Coop OM & JCoopOM & & N.A. & N.A. & & & 1 & 1 \\
\hline 35 & Journal of Technology Management \& Innovation & JTMI & & N.A. & N.A. & 1 & & & 1 \\
\hline 36 & Journal of Health Organization and Management & JHO\&M & & N.A. & N.A. & 1 & & & 1 \\
\hline 37 & Social Responsibility Journal & Soc.Res.J. & & N.A. & N.A. & 1 & & & 1 \\
\hline 38 & Systems Research \& Behavioral Science & SR\&BS & 1.03 & N.A. & N.A. & & 1 & & 1 \\
\hline 39 & Book Chapters & Bk. Chap. & & N.A. & N.A. & 2 & & & 2 \\
\hline 40 & Working Papers & Wkg. Pap. & & N.A. & N.A. & 3 & & & 3 \\
\hline 41 & Dissertations & PhD.Diss. & & N.A. & N.A. & 6 & 1 & 2 & 9 \\
\hline & & & 3.58 & & & 31 & 26 & 12 & 69 \\
\hline
\end{tabular}

Legend:

- $\boldsymbol{A} \boldsymbol{b} \boldsymbol{b}$. . $=$ Abbreviation; Imp. $\boldsymbol{F}$. = impact factor of the publication; AJG 2018; Academic Journal Guide of the Chartered Association of Business Schools - Balanced, Paradox, Stakeholder $=$ the three subsamples in the full sample

The full sample of 69 selected papers include 55 (80\%) journal articles. Of the 55 journal articles, $44(80 \%)$ have been published in journals that are included in the AJG 2018. Further, of the 44 journal articles published in the AJG 2018 journals, nearly two-thirds, i.e., $64 \%$ (28 articles) have been published in the top two (in terms of quality) journal categories. These 28 articles comprise nearly half (i.e., 48\%) of the full sample. These numbers suggests that the overall quality of the full sample of papers being reviewed in this manuscript is quite high. Another metric that supports this conclusion is that 43 articles (62\% of full sample) were 
published in one of 26 journals that were included in the 2016 Journal Citation Reports, and the average impact factor of these journals is an impressive 3.58 .

\section{Analysis}

The full sample of selected papers encompasses a wide range of disciplines. For instance, the 44 articles that have been published in 27 journals included in the Academic Journal Guide (AJG) 2018 (published by the Chartered Association of Business Schools) cover 12 of the 22 AJG 2018 disciplinary areas, i.e., 55\% of the total scope of the AJG 2018. This speaks to the general relevance and applicability of this manuscript's focal area, i.e., the intersection of paradox theory and stakeholder theory.

Further, of the 12 AJG 2018 disciplinary areas included, 22 articles (i.e., 50\% of AJG 2018 subsample and $32 \%$ of the full sample) are accounted for by the General Management, Ethics, Gender, and Social Responsibility (with the other 50\% AJG 2018 articles spread across 11 other disciplinary areas, with each one of them accounting for between $2 \%$ and $7 \%$ of the AJG 2018 subsample). The disproportionate number of papers in the General Management, Ethics, Gender, and Social Responsibility area could be explained by three factors: (1) it is quite a wide area, as compared to, for instance, Strategy, or Innovation, or Marketing; (2) the three domains of this manuscript, i.e., paradox theory, stakeholder theory, and performance management, all relate to general management, which is the lead term for this disciplinary area; and (3) managing stakeholders and holistic performance management, are particularly relevant to two of the three sub-areas included in the disciplinary area title, i.e., ethics and social responsibility.

Of the 38 journals (27 AJG 2018 and 11 others) from which the sample has been drawn, the journal that has contributed the largest number of articles (10, or $15 \%$ of the full sample) is the Journal of Business Ethics. This is not only unsurprising but also heartening because it 
supports the underlying normative or ethical core of this paper, i.e., the intersection of paradox theory and stakeholder theory contribute to a more balanced, holistic, and ethical approach to managing organizations which results in superior, sustainable, corporate performance.

Finally, despite the relative newness of stakeholder theory and paradox theory, the time period encompassed by the selected papers is quite wide. The time frame of the sample is 17 years from 2002 (Wheeler et al. 2002) to 2018 (Hoffman 2018). This compares well with Van der Byl and Slawinski's (2015) review of the corporate sustainability literature, with regard to win-wins, trade-offs, and paradoxes, which had a range of 11 years, from 2005 to 2014.

\section{Subsample analysis.}

The full sample of 69 papers comprise 31 (45\%) in the balanced subsample (Appendix 1A), $26(38 \%)$ in the paradox-oriented subsample (Appendix 1B), and $12(17 \%)$ in the stakeholderoriented subsample (Appendix 1C). Each Appendix lists the scholarly output, its year of publication, its AJG 2018 rating, its impact factor, its author/s, its type (i.e., review, theory, or empirical) and its primary and secondary foci (typically first and second keywords). With regard to type, a scholarly output can fall into more than one category (e.g., both review and qualitative research). With regard to foci, in the rare cases where the first two or more keywords are either synonyms or closely-related, then the next distinct keyword is taken as the secondary focus. Thus, for instance, from Smith et al's (2013) keyword stream (social enterprise, social entrepreneur, paradox theory, institutional theory, organizational identity, hybrid organizations) the primary and secondary foci selected were 'social enterprise' and 'paradox theory'.

That the paradox-oriented subsample contains more than double the number of papers in the stakeholder-oriented subsample suggests that paradox scholars recognize the application of their theorizing to stakeholder management (for instance, it is the basis of the performing 
paradoxes definition) whereas stakeholder theorists are not looking as much to paradox theory barring some notable exceptions (e.g., Cornforth 2004; Mason and Doherty 2016). It therefore appears that stakeholder management is more central to paradox theory, than the concept of paradoxes is stakeholder theory. The lack of application of paradox theory to stakeholder management is exemplified by the fact that a relatively recent stakeholder theory review paper (Parmar et al. 2010) mentions the word 'paradox' only once, and that too not in the body of the paper, but rather in the References section, as it is the title of a cited work.

Time frame. Of the three subsamples, the stakeholder-oriented subsample is the oldest (only 2, i.e., 17\%, papers have been published since 2013), whereas the paradox-oriented subsample is the most recent (92\% published since 2013). This is not surprising and reflects the relatively maturity of stakeholder theory compared to paradox theory, which is quite new. The balanced subsample, perhaps aptly, falls in-between (77\% published since 2013). Interestingly, the balanced subsample contains both the oldest (Wheeler et al. 2002) and the newest (Hoffman 2018) papers of the full sample. Even more interestingly, the oldest paper contains both key words 'paradox' and 'stakeholder' in its title, suggesting that the connection between their respective theories may have been apparent as far back as nearly two decades ago. Further, this paper includes both corporate social responsibility (CSR) and sustainability among its four keywords, and these two domains continue to be relevant areas (as will be shown later) for the intersection of paradox and stakeholder theories.

Quality. The paradox-oriented subsample has the highest quality, the stakeholder-oriented subsample has the lowest quality, and once again, the balanced subsample falls in-between. Nearly 90\% (i.e., 88.5\%) of the paradox-oriented subsample have been published in AJG 2018 journals and the average impact factor of journals in this subsample is 4.27 , as compared to the 
balanced subsample $(42 \%, 4.10)$ and the stakeholder sample $(67 \%, 2.86)$. The relatively low proportion of AJG 2018 papers in the balanced subsample as compared to the other two subsamples, can be explained by the fact that it includes three working papers (100\% of working papers in full sample) and a disproportionate number of doctoral dissertations (67\% of doctoral dissertations in full sample). The large proportion of recent doctoral dissertations (all published since 2004 and half of them in 2016) in the balanced subsample suggests that emergent work is at the intersection of paradox theory and stakeholder theory.

Methodology. In terms of methodology, the breakdown of the papers in the balanced subsample is, funnily enough, the most balanced, with roughly one-third of the sample in each category, i.e., review (35\%), theory (30\%), and empirical (37\%). Review papers are relatively scarce in the other two subsamples, i.e., $4 \%$ for the paradox-oriented subsample, and $0 \%$ for the stakeholder-oriented subsample. With regard to the split between theory and empirical research, the paradox-oriented subsample is relatively balanced (i.e., $42 \%$ theory, $54 \%$ empirical), unlike the stakeholder-oriented subsample which is greatly skewed toward theory (i.e., 83\%) as compared to empirical (17\%) papers. That the stakeholder-oriented subsample is so heavily skewed toward theory and so sparse with regard to empirical research is not surprising. As Kraatz and Block (2008, p. 44) put it, "stakeholder theorists have based their arguments upon moral philosophy, upon practical reasoning, and to a lesser extent upon empirical research." However, the fact that there are more paradox-oriented empirical papers in both an absolute (across subsamples) sense and relative (within subsample) sense is very encouraging from a management research and practice perspective, since paradox could be perceived to be an abstract construct, which is difficult to operationalize, measure, or apply in real-life. In terms of methodologies applied, there is a skew toward qualitative techniques (20) compared to 
quantitative techniques (7). This is not surprising because both paradox and stakeholder theory are meta-theories and hard to operationalize using traditional quantitative techniques. The qualitative techniques applied include case study analysis (9), narrative analysis (2), interviews (2), ethnographies (2), and discourse analysis (2), among others.

Article Foci. Examining the primary and secondary keywords in the selected articles reveals, unsurprisingly that paradox and stakeholder-related terms are the most common. The relatively lower percentages for stakeholder terms as compared to paradox terms suggest that stakeholder theory is more mature compared to paradox theory and is therefore being applied to a greater range of substantive fields, whereas the paradox theory articles are still mostly about paradox as would be expected in its current emergent state. The frequency distribution of the non-paradox or stakeholder keywords is presented in Appendix 2. As one will notice, some of these keywords are closely related or overlap to some extent. Therefore a summary frequency distribution of these keywords grouped by the main theme, wherever necessary, is presented in Table 3 . Seven domains account for $74 \%, 42 \%$, and $67 \%$ respectively of the primary keywords and $32 \%, 23 \%$, and $33 \%$ of the secondary keywords, in the balanced, paradox-oriented, and stakeholder-oriented subsamples respectively. The findings from each of these domain areas are discussed in the next section.

Interestingly, almost none of the papers in the full sample are explicitly about performance management. The only exception being Bosch-Badia et al. (2013) whose second keyword is 'corporate financial performance'. This suggests that although scholars realize that there is a close connection between paradox theory and stakeholder theory they have not crystallized that to focus on performance management which is a vital aspect of management theory and practice. And this is an important contribution of this paper. 


\section{Table 3: Frequency distribution of key topics in the selected papers}

\begin{tabular}{|c|l|c|c|c|c|c|c|c|}
\cline { 3 - 9 } \multicolumn{2}{c}{} & \multicolumn{2}{c|}{ Balanced } & \multicolumn{2}{c|}{ Paradox-oriented } & \multicolumn{2}{c|}{ Stakeholder-oriented } & \multirow{2}{*}{ Total } \\
\hline$\#$ & Key words & Primary & Secondary & Primary & Secondary & Primary & Secondary \\
\hline 1 & Sustainability-related & 5 & 4 & 6 & 1 & 1 & 17 \\
\hline 2 & Governance-related & 5 & 1 & 1 & & 4 & & 11 \\
\hline 3 & Corporate Social Responsibility & 4 & 2 & 1 & & 3 & 1 & 11 \\
\hline 4 & Social Enterprises/Non-profit & 2 & 1 & 1 & 2 & & 3 & 9 \\
\hline 5 & Sustainable HRM/Careers & 4 & 1 & & & & 5 \\
\hline 6 & Change Management-related & 2 & & 1 & 2 & & & 5 \\
\hline 7 & Legitimacy and Institutional Theory & 1 & 1 & 1 & 1 & & & 4 \\
\hline
\end{tabular}

\section{Findings}

The constructs at the intersection of the two focal theories have been shown in Figure 1, which also shows some of the constructs from each of the two theories that do not fall within the intersection. Whereas all the constructs at the intersection (i.e., colored area) are discussed in the main text, not all the ones in the non-intersecting areas are discussed. These latter constructs, listed outside the colored intersection area, are meant to be illustrative and not exhaustive, as indicated by the fact that the two non-intersecting areas are not closed.

In this paper, the term construct refers to a concept or a label for something which cannot be directly observed (Cronbach and Meehl 1955; Shadish et al. 2002). It is thus hypothetical (Cronbach and Meehl 1955) and is a key building block for theory building (Doty and Glick 1994; Dubin 1969). For a concept to become a construct it needs to be theoretically defined or postulated (Cronbach and Meehl 1955) and is thus the product of the scholar's mind. This also implies that the entry barriers to construct articulation are low, and this typically gives rise to construct proliferation i.e., "the accumulation of ostensibly different but potentially identical constructs representing organizational phenomena" (Shaffer et al. 2016, p. 80). Construct proliferation is salient problem both in social sciences generally (e.g., Hershcovis 2011; Shaffer et al. 2016; Tornau and Frese 2013) and in the CSR/sustainability research domain specifically 
(e.g., van Marrewijk 2003). This accounts for the variety in labels and nomenclatures that are apparent in Figure 1.

Figure 1: Constructs at the intersection of Paradox Theory and Stakeholder Theory

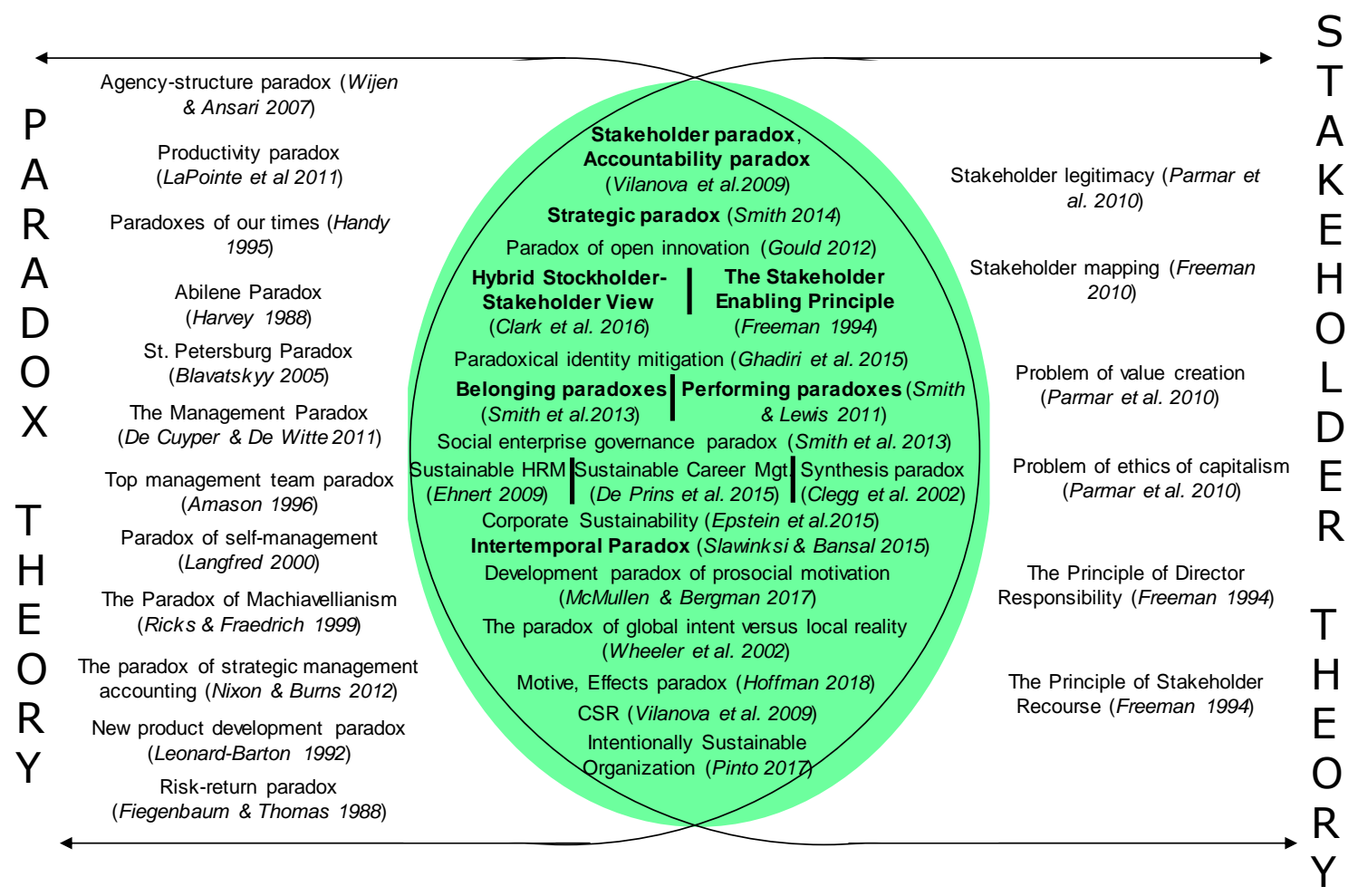

The 21 constructs in the intersection area can be grouped into the following two broad categories: (a) general constructs (8); and (b) domain-specific constructs (13). The former are highlighted in Figure 1 to clearly distinguish them from the latter. The general constructs are discussed in the next subsection whereas the domain-specific constructs are discussed within their individual subsections under the broad heading of domain-specific findings. In this paper, a domain refers to a research stream that could be either theory- or construct-related (e.g., CSR, corporate sustainability) or phenomenon-related (e.g., social enterprises). The specificity of the review has resulted, not surprisingly, in a somewhat cohesive and overlapping set of research domains, which I have attempted to delineate into distinct streams by striking a balance between 
recognizing domains (whether established, like sustainability or governance or emergent, like sustainable HRM/careers) and overly fragmenting the field.

\section{General constructs at the intersection.}

Even though 'performance management' was absent from the primary and secondary keywords in the articles reviewed, amongst the general constructs at the intersection of the two theories, its centrality is paradoxically both obvious and implicit, as will be revealed in the following discussion. This finding is important because it buttresses this paper's main thesis about performance management being at the intersection of the two focal theories.

The clearest example of this (as is obvious from the following highlighted text) is the performing paradox (Smith and Lewis 2011) construct which stems from the plurality of stakeholders and the resulting competing strategies and goals. Since multiplicity of elements is at the intersection of the two theories, it is not surprising that 'plurality' in general, and with regard to performance objectives in particular, is a factor that connects or bridges paradox and stakeholder theories. Smith (2014) illustrates how a particular performing paradox, the tension between innovation and existing products business plans, was addressed by senior leaders by engaging multiple stakeholders including, clients, leaders from other units, and subordinates, to better clarify uniqueness and distinctions. Another example of a performing paradox emerging from the plurality of stakeholders, in the context of banking risk management, is provided by Lim et al. (2017). The individual banker is faced with the paradox of arranging loans that might generate good interest income for the bank (in line with shareholder expectations) but which might also increase the risk rating of the bank (a key regulatory aspect).

Apart from plurality, performing paradoxes can also be intensified by scarcity conditions, as managers have to meet competing yet coexisting demands with limited resources resulting in a 
tug-of-war between internal and external stakeholders (Schad et al. 2016; Smith 2014). Thus, scarcity could be a factor that creates or aggravates the conflict between the multiple interests. And as pointed out earlier, conflict between the multiple elements is an intersection point for the paradox theory and stakeholder theory.

Finally, organizational change situations also intensify performing paradoxes as new capabilities compete with existing competencies, often rendering them obsolete (Huy 2002; Lüscher and Lewis 2008; Schad et al. 2016). This too is not surprising because change, like scarcity, creates or intensifies conflict. However, in this case the conflict is essentially temporal (i.e., the old versus the new) with regard to the ways of doing things.

There are two other constructs that are closely allied to the performing paradox (Smith and Lewis 2011) construct. These are, strategic paradox (Smith 2014) from the paradox literature, and stakeholder enabling principle (Freeman 1994) from the stakeholder literature. According to Smith (2014, p. 1593), "strategic paradoxes describe organization-level performing paradoxes that stem from the plurality of stakeholders and result in competing strategies and goals." This aspect is mirrored, from a stakeholder theory perspective by the stakeholder enabling principle (Freeman 1994, p. 417) which states that "corporations shall be managed in the interests of its stakeholders, defined as employees, financiers, customers, employees, and communities." These paradoxes can also arise simply from different stakeholders interpreting organizational outcomes differently (Jay 2013; Schad et al. 2016). Further, these differences whether in interests or interpretations are intensified with greater environmental complexity and increased plurality of stakeholders holding competing yet equally valid views (Adler et al. 1999; Denis et al. 2012; Scherer et al. 2013). 
With regard to managing the competing interests of different stakeholders, paradox theory suggests they should be accepted, i.e., the organization must acknowledge multiple 'truths' and that there is not necessarily a simple solution (Smith and Lewis 2011; Hillebrand et al. 2015). This is directly relevant to the thesis of this paper, because it militates against adopting simplistic, linear, myopic, single stakeholder-focused performance management systems. An example of the acceptance of the inter-stakeholder tension is the hybrid stockholder-stakeholder view in which neither the stockholder dimension nor the stakeholder dimension is privileged (Clark et al. 2016). Clark et al. (2016) interpret this mingling of values as a synthesis (Poole and Van de Ven 1989), which is also an approach to accommodating competing or oppositional ideas. In keeping with paradox theory, they too argue that the hybrid (i.e., accepting or synthesizing) perspective does not actually resolve the tension between the stakeholder and stockholder approaches, but rather it depends on different stakeholder groups interpreting the same information in different ways (Clark et al. 2016).

Another construct which directly speaks to ineffective performance management in general, and the prioritization of the short-term over the long-term (cf. annual-earnings-growth trap, Dodd and Favaro 2006) in particular, is the intertemporal paradox. The intertemporal paradox refers to the fact that organizations "tend to focus on the short term at the expense of the long term, even if they face suboptimal long-term organizational outcomes (Slawinski and Bansal 2015, p. 531).” It is not really a paradox or perhaps a poorly managed one, but it is nevertheless a relevant construct, because it speaks to managing a conflict, albeit suboptimally, which may involve prioritizing stakeholders whose demands are short-term over stakeholders whose demands are more long-term. This construct is by definition inimical to the long-term health of the organization and should therefore be managed in a manner suggested by paradox 
theory, e.g. the both/and approach (Cornforth 2004; Hahn et al. 2014; Lewis 2000) or synthesis (Poole and Van de Ven 1989).

Two other general constructs at the intersection are the stakeholder paradox (discussed earlier) and the accountability paradox, which suggests that the more an organization attempts to be transparent and communicative to its various stakeholders through various media, the greater the loss of coherence with regard to its identity and vision (Vilanova et al. 2009). The latter paradox, rather than addressing performance management issues directly, speaks to the communication of performance to various stakeholders. Thus, this paradox is indirectly concerned with performance management because attempting to communicate heterogeneous results, individually to each set of stakeholders, could result in messages getting mixed and blurred especially if communicated via social media, which is in the public domain by definition.

Belonging paradoxes (which, along with performing paradoxes, are two of the four fundamental organizational paradoxes) also lie at the intersection of the two focal theories, particularly in social enterprise stakeholder management (Smith et al. 2013). Belonging paradoxes "arise between the individual and the collective, as individuals and groups seek both homogeneity and distinction" (Smith and Lewis 2011, p. 383). Prima facie, it may appear that belonging paradoxes have no connection or relation to performance management, but they do, it just happens to be at a deeper level. For instance, Smith et al. (2013) argue that whereas some stakeholders (e.g., donors, foundations) have identities that are aligned with that of a social enterprise, others (e.g., customers, suppliers) often have identities that diverge from that of the social enterprise. If these multiple stakeholders simultaneously attempt to connect with the social enterprise through their individual particular identities it would create a belonging tension for the 
social enterprise in terms of its positioning (Smith et al. 2013) and this in turn could adversely affect performance.

\section{Domain-specific findings.}

As identified earlier, through the analysis of the primary and secondary keywords, presented in Table 3, there are seven domains (apart from paradox- and stakeholder-related) which account for most of the selected articles. These domains in order of the prevalence of their associated keywords are as follows: (1) sustainability; (2) governance; (3) corporate social responsibility (CSR); (4) social enterprises; (5) sustainable HRM and careers; (6) change management; and (7) legitimacy and institutional theory. The substantive findings across all seven domains overlap, in that they are largely related to either performance management or the communication of performance (e.g. Clark et al. 2016; Hoffman 2008; Vilanova et al. 2009).

Further, these seven domains exemplify Smith and Lewis' (2011) argument that organizational paradoxes in general, and performing paradoxes in particular, become especially salient under conditions of plurality, change, and scarcity. The plurality of stakeholders is relevant for both governance (\#2) and legitimacy (\#7). Also, certain stakeholders become more salient and important in certain domains, e.g. environment in the case of sustainability (\#1) and sustainable HRM and careers (\#5), or society in the case of CSR (\#3) and social enterprises (\#4). Change is clearly at the heart of change management domain (\#6), whereas scarcity is an important factor for both social enterprises (\#4) who typically have to achieve their goals with limited resources and for those in the sustainability (\#1) domain who are trying to conserve and/or replenish scarce natural resources.

Although I have attempted to group these into seven discrete categories there are several papers that encompass two or more of these domains. For instance, Ocasio and Radoynovska's 
(2016) article encompasses three domains, governance, change management, and institutional theory, whereas Mason and Doherty's (2016) article is at the intersection of social enterprises and governance. But in general each of these seven domains is reasonably distinct.

\section{Sustainability.}

Sustainability acknowledges multiple stakeholders (e.g., people, planet, and profits, i.e., shareholders) and therefore necessarily involves tensions. If these tensions are juxtaposed and treated as paradox, rather than polarized, it would facilitate development of more creative solutions and long term alignment between business goals and societal needs (Gao and Bansal 2013; Slawinski and Bansal 2015), and thereby more effective performance management.

Sustainability results from an equilibrium between economic, ecological, and social factors (Froese 2017). Taking a cognitive perspective, Hahn et al. (2014) highlight the differences between the simplistic business case frame which focuses only on the economic attributes and the complex paradoxical frame which combines economic, environmental, and social attributes, in effect, a multiple stakeholder perspective. Similar to Miron-Spektor et al. (2018) they argue that the more paradoxical the cognitive frame of decision makers, the more likely they are to notice a wide range of aspects of numerous sustainability (and stakeholder) issues (albeit with less detail) and adopt a more prudent stance on them. This in turn would facilitate a more balanced and holistic performance management model. Further supporting the underlying thesis of this paper, Hahn and colleagues argue for a more balanced temporal orientation in performance management (Hahn et al. 2014, 2015). They aver that long-term orientation is necessary to consider the interests of multiple stakeholders (Hahn et al. 2014), and the short-term versus long-term tension (Dodd and Favaro 2006) can be reconciled by rewarding managers for 
both short-term financial outcomes and long-term non-financial objectives in line with demands of non-stockholder stakeholders (Hahn et al. 2015).

Pinto $(2016,2017)$ provides an illustration of such an effective, holistic, balanced performance management approach in his analysis of the Icehotel which developed a successful business enterprise (which has lasted over 25 years), and brought much-needed employment and other benefits to the local community (located in the Tundra), during the bitter Arctic winter, by juxtaposing and enshrining paradoxes at its core, i.e., ice (hard, cold) with hotel (comfortable, warmth). Pinto's (2017) definition of an intentionally sustainable organization (ISO) incorporates both paradox theory and stakeholder theory, when he describes an ISO as one which takes a balanced and bifocal approach to stakeholder management and is built on deliberately constructed, enshrined, and managed paradoxes, among other aspects. Pinto's (2017) approach to both stakeholder and paradox management is essentially cognitive, and this approach is supported by Galuppo et al. (2014) who, based on a review of the sustainability literature suggest that cognitive mechanisms such as 'paradoxical thinking' and reflexivity are key levers for dealing effectively with multiple stakeholders and more socially sustainable organizing.

\section{Governance.}

"Corporate governance is the process by which corporations are made responsive to the rights and wishes of stakeholders" (Demb and Neubauer 1992, p. 9) and paradox theory has been proposed as a means to understand both for-profit and nonprofit governance (Hough et al. 2005). Cornforth (2004) endorses the underlying thesis of this paper when he argues that unlike other theories (e.g., agency theory, stewardship theory) that tend to be one-dimensional, paradox theory recognizes that management problems require a move from linear thinking and simple either/or choices. Because it is precisely this sort of one-dimensional, linear, simplistic approach 
to performance management that is sought to be combated by the combination of paradox theory and stakeholder theory.

Also, in the corporate governance literature, the stockholder and stakeholder perspectives are presented as alternative, normative and oppositional sets of beliefs about how firms should be managed (Donaldson and Preston 1995; Clark et al. 2016). In practice these tensions could be more integrated as when organizations accept these tensions in their corporate communications (CEO letters) by strategies such as book-ending, cadence, continuous co-mingling, simultaneous co-mingling, and hybridization (Clark et al. 2016). However, these 'artful' rhetorical strategies are superficial and merely obscure the tensions rather than resolve them in a productive manner (Clark et al. 2016) and effective performance management implies going beyond mere words.

\section{Corporate Social Responsibility (CSR).}

The earliest work in our sample (Wheeler et al. 2002) focuses on CSR. It explores the paradoxes and dilemmas faced by firms in the extractive sector when they attempt to adopt a more stakeholder-responsive orientation towards CSR. Wheeler et al. (2002) find that some firms manage the paradox of global intent versus local reality better than others, and those who do derive benefits both for stakeholders and for the business, which is consonant with the thesis of this paper. At the individual-level, Ghadiri et al. (2015) found that CSR consultants dealt with opposing stakeholders' performance-related pressures (i.e., profit and social responsibility) on their identity by engaging in paradoxical identity mitigation, "a process whereby the concomitant and paradoxical use of linguistic strategies is aimed at simultaneously embracing and distancing oneself from contradictory identity demands (Ghadiri et al. 2015, p. 593)", a tactic that is related to both belonging and performance paradoxes. 
Adopting a 'Communications Constitutes Organizations' perspective, Hoffmann's (2018) qualitative meta-analysis shows that four potential CSR paradoxes have been talked into nonexistence. Of these, two, i.e., the effects paradox and the motive paradox, involve stakeholders. The effects paradox (Hoffman 2018) states that CSR effects which are desirable on ethical grounds (i.e., societal stakeholder) may have negative consequences from a business point-of-view (i.e., investor stakeholder), which highlights the performance-management related tension that is inherent in applying stakeholder theory in general, and in simultaneously addressing two stakeholders' (i.e., society and investor) needs or goals in particular. The motive

paradox states that organizations may engage in CSR for extrinsic or profit-seeking motives but society needs to believe that its motives are purely intrinsic and organizations are therefore advised to not 'over-communicate' CSR and play down the salience of firm-serving benefits, which are an instrumental rationality (Hoffman 2018). Once again, just as Clark et al. (2016) showed, the motive paradox construct highlights the approach that some firms take - try to get away from the conflicts or tensions by paying lip-service to multi-stakeholder management and not doing anything substantive.

\section{Social Enterprises.}

Social enterprises have to deal with two competing performance goals or demands (i.e., commercial and social), and paradox theory in general, and paradoxical leadership in particular, could help them avoid either losing their dual focus or becoming mired in intractable conflicts between the two stakeholder camps (Smith et al. 2012). Based on their qualitative analysis of nine hybrid (social enterprise) organizations, Kannothra et al. (2017) contribute to a better understanding of paradox dynamics (Schad et al. 2016) in the following two ways: Firstly, by identifying stakeholder-oriented growth orientations, like 'community-focused' and 'client- 
focused' as important drivers for how performing paradoxes are perceived and managed, and; secondly, by identifying the divergence between entrepreneurial aspiration and organizational configuration as a critical driver in making performing paradoxes salient.

The fundamental purpose of a social enterprise is to make a difference, and the stakeholders that potentially benefit include, employees, beneficiaries, communities, families, and funding partners, each of whom could have different objectives and a different notion of success (Mason and Doherty 2016; Smith et al. 2013). Thus, the divergent goals, metrics, and stakeholders in a social enterprise (i.e., social enterprise governance paradox), create both belonging paradoxes (discussed earlier) and performing paradoxes (Smith et al. 2013). The latter also arise with regard to sustaining the commitments to conflicting goals over time, because the tendency is for one goal or set of goals to dominate the rest (Smith et al. 2013). An example of this is McMullen and Bergman's (2017) process model of the development paradox of prosocial motivation wherein the prosocial motivation that encouraged the laudable creation of social value is paradoxically used to justify the exclusion of new competitors who may be offering similar or even superior solutions.

Another example of the close connection between belonging paradoxes and performing paradoxes is provided by Mason and Doherty (2016). They examined how fair trade social enterprises (FTSEs) managed paradoxes in stakeholder-oriented governance models. They identified stakeholder representation on the board and its consequential impact on the board's collective identity as constituting a belonging paradox. They also found that FTSEs embrace board-level plurality and participation by encouraging stakeholder governance which in turn helps resolve the belonging paradox. However since paradoxes are by their very nature persistent, managing governance paradoxes entails a continuous cycle of articulating (and 
rearticulating) them and responding to mitigate them (Mason and Doherty 2016). This cyclical process, over time, increases a board's competence at understanding and managing paradoxes (Mason and Doherty 2016), and in turn leads to more effective governance, and performance management, i.e., performing paradoxes.

\section{Sustainable HRM and Careers.}

Performance management and development processes are an intrinsic part of HRM and strategic HRM (Wright et al. 2001; Wright and Snell 1998). Not surprisingly they are core to sustainable HRM as well. This is obvious from its definition as "the adoption of HRM strategies and practices that enable the achievement of financial, social, and ecological goals, with an impact inside and outside of the organization and over a long-term horizon while controlling for unintended side effects and negative feedback [emphases added]" (Ehnert et al. 2016, p. 90). The connection between sustainable HRM and the thesis of this paper is clear from the highlighted phrases. To reiterate, sustainable HRM is about achieving multiple goals, across multiple stakeholders, over a long-term horizon, without causing unintended side effects. With regard to the longer-term dimension of performance management, De Prins et al. (2015, p. 327) define sustainable career management as "all the processes and practices that manage the development of individuals along a path of experiences and jobs, with respect for employees, openness towards different stakeholders and in view of continuity."

And a performance management system that causes negative unintended side effects as described by sustainable HRM would be discouraged by a combination of paradox theory and stakeholder theory. Sustainable HRM scholars appear to agree. Paradox theory (Ehnert 2009) and stakeholder theory (Ehnert 2009; Zaugg 2009) are two of the three approaches (along with the 'theory of negative externalities and stakeholder harm') that are considered to be appropriate 
theoretical lenses for operationalizing sustainable HRM (Ehnert et al. 2016; Guerci and Pedrini 2014; Savaneviciene and Stankeviciute 2014). Whereas both Zaugg's (2009) and Ehnert's (2009) models of sustainable HRM have stakeholder theory at their core, Ehnert's (2009) model also incorporates paradox theory.

Lastly, sustainability, defined as balancing consumed and reproduced resources, creates visible and manageable paradoxical choices, situations, and tensions that not only need to be managed but also can be a source of innovation and change (Ehnert et al. 2016; Kozica and Kaiser 2016). In this regard, the synthesis paradox (Clegg et al. 2002) and a both/and approach to dynamic equilibrium (rather than one based on fit or alignment) is helpful (De Prins et al. 2015). This would facilitate the use of strategic HRM practices to both maximize profits and minimize harm to stakeholders, since these polarities are not mutually exclusive but rather mutually reinforcing (De Prins et al. 2015).

\section{Change Management.}

The change management domain can be parsed along two lines: (1) triggers or drivers of change; and (2) managing organizational change interventions. In the former case, if the organization does not respond to the triggers or drivers of change it risks declining performance which may result in it becoming defunct. In the latter case, the key underlying challenge is to manage the change in as smooth as possible to minimize the usually concomitant drop in performance (cf. valley of despair, Schneider and Goldwasser 1998).

With regard to change drivers, recent work in paradox theory (Lewis and Smith 2014) in particular and organization theory in general (Ocasio and Radoynovska 2016) has shown that organizations operate in complex, pluralistic environments characterized by multiple, competing, and often contradictory logics (Gould 2012) and therefore have to constantly respond to change 
imperatives. And although organizational scholars have historically neglected applying the paradox approach to change management (Smith and Lewis 2011), Jansson (2015) seeks to remedy this situation by attempting to explain how persistent and pluralistic tensions among different stakeholders influence organizational change and vice versa. According to Ocasio and Radoynovska (2016) paradox theory emphasizes discontinuity as means of exposing latent contradictions which can be framed as either incompatible (i.e., either/or) or paradoxical (i.e., both/and). The former can be addressed through differentiation, i.e., modifying the business model while preserving the governance strategy, whereas the latter can be addressed through integration, i.e., modifying both business model and governance strategy (Ocasio and Radoynovska 2016).

With regard to change management, multiplicity of stakeholders could lead to ambiguity about outcomes and uncertainty about value capturing. In the context of change and innovation in a hybrid organization (i.e., a public-private entity), Jay (2013) found that it suffered from a performing paradox in that there was ambiguity about whether certain outcomes represented success or failure. In a similar vein, Gould (2012) makes the case that stakeholder theory and stakeholder engagement provide the keys to resolve the paradox of open innovation, i.e., the desire to reap the benefits versus the risk of others' appropriating the benefits. He suggests that building relationships through stakeholder engagement enhances the organizations knowledge management competencies, and although knowledge may inadvertently seep out of the organization, it may inadvertently seep in. Further, by contextualizing open innovation it would create knowledge that goes beyond the specifics of any one expert involved in the process, thereby minimizing the risk of appropriation (Gould 2012).

\section{Legitimacy and Institutional Theory.}


As pointed out earlier, the risks to legitimacy that emanate from ineffective performance management systems are considerable, and could even result in organizational deaths (e.g., Enron, Parmalat). This position is endorsed by corporate governance scholars. For instance, Scherer et al. (2013, p. 259) states that "in the face of heterogeneous environments with conflicting demands, corporations that follow a paradox approach are more likely to be successful in preserving their legitimacy" than those that follow either a one-best-way approach or a contingency approach. Similarly, Bednarek (2011) opines that although prior work has typically associated each organization with a single dominant strategy, in pluralistic contexts, paradoxical combinations of strategies could promote legitimacy. Finally, with regard to institutional theory, Smith and Tracey (2016) suggest that combining its insights with those of paradox theory would help leaders address competing demands simultaneously and contribute to organizational success.

\section{Discussion}

The use of MBO-type performance management systems is both ubiquitous - be it sports, business, government, or even religion (Grizzle 2002) - and well-established as management practice (Drucker 1954; Odiorne 1965). Despite this long history, these performance management systems often result in unintended negative side effects which can sometimes be disastrous for individuals, organizations, and society. This is typically because the objectives are too narrow, myopic and short-term. However taking a more balanced approach, by focusing on a broader set of objectives, across multiple stakeholders (as consistent with stakeholder theory) is, inter alia, cognitively challenging. And this is where an essentially cognitive theory, like paradox theory, which focuses almost exclusively on the challenge at the heart of effective stakeholder and performance management, i.e., managing conflicts or tensions between multiple elements, 
comes in. It provides a variety of approaches that could be harnessed to manage inter-stakeholder tensions and conflicts effectively. This in turn would lead to more effective organizational performance management and better organizational outcomes. Thus, the key to effective performance management lies at the intersection of paradox theory and stakeholder theory. Accordingly, the literature at the intersection of these two focal theories was reviewed. This review identified 69 scholarly outputs (31 balanced across both theories, 26 paradoxoriented, 12 stakeholder-oriented). Based on this review, seven domains and 21 constructs located at the intersection of both focal theories were identified. It is interesting to note that all the domains and constructs dealt directly, or indirectly (e.g., communication of results), with performance management, which supports the main thesis of this paper.

Further, the fact that none of the source articles at the intersection of the two focal theories had 'performance management' as either the primary or secondary keyword, highlights the key contribution of this paper. It has built a bridge between the two theories and made explicit (the hitherto implicit) important insights for performance management that lay at the intersection. Future research could investigate this intersection more deeply to provide further substantiation with regard to performance management. But apart from performance management, as pointed out earlier, this intersection of two general, meta-theories, has relevance and applicability across a wide range of academic disciplines, and future research could identify other areas of management research and practice that could benefit from this complementarity.

Although this review identified seven domain areas, as pointed out earlier, these are a relatively cohesive and overlapping set of domains, most of which (e.g., sustainability, CSR, social enterprises) could be considered the 'sunrise sectors', i.e., areas which are being actively studied because of their importance for a better tomorrow. Thus, this paper would encourage 
more focused and systematic research in these important domains. And this in turn could lead to more effective organizational and performance management in the sectors that are arguably the most important for the future of the planet and the future of society.

All seven domain areas are affected by one or more of the three conditions, i.e., plurality, change, and scarcity, that make latent organizational paradoxes in general, and performing paradoxes in particular, salient (Smith and Lewis 2011). Work in four of these domains (i.e., sustainability, governance, CSR, and social enterprises), is relatively developed, hence more scholarly attention needs to paid to the other three domains, i.e., sustainable HRM and careers, change management, and legitimacy and institutional theory. However, this does not imply that research in the first four domains should be neglected. It should, in fact, be accelerated because of the importance of those topics. For instance, as climate change and global warming are becoming increasingly salient, urgent and important (Collins and Zheng 2015; Slawinski and Bansal 2015), sustainability and related issues like governance and CSR will become vital not just for the survival of organizations, but for the survival of the planet. Finally, more research is needed to identify which other domain areas, apart from these seven, are impacted by plurality, change, and scarcity, so that research at the intersection of the two focal theories could be proactively and fruitfully applied to them.

It is interesting that the work that is balanced between both focal theories is more emergent, (i.e., in recent dissertations and working papers), for three reasons. Firstly, because it suggests that work on this intersection will thrive going forward, as this new cohort of scholars (who are focused on the mutual dialogue and interplay between these two theories), will continue to develop their lines of research. Secondly, more work at the intersection implies that there may be more constructs and domains identified in the future. Finally, it implies, as alluded to earlier, 
that apart from performance management there may be other application areas that could benefit from work at this intersection.

Although, two of the four fundamental organizational paradoxes, i.e., performing and belonging (Smith and Lewis 2011) are included in the intersection area, the other two, i.e., learning paradoxes (which are knowledge-related) and organizing paradoxes (which are process-related) are not. This begs the question, do they fall outside the intersection area by definition, or have not been included simply because there has not yet been work at the intersection. I believe the answer is the latter, as I explain below.

According to paradox theory, learning paradoxes "surface as dynamic systems change, renew, and innovate. These efforts involve building upon, as well as destroying, the past to create the future" (Smith and Lewis 2011, p. 383). Drawing on this, can there be stakeholderrelated learning paradoxes which build upon as well as destroy past approaches to stakeholder management as either stakeholders themselves change or the power balances among the same set of stakeholders change? Similarly, organizing paradoxes "surface as complex systems create competing designs and processes to achieve a desired outcome. These include tensions between collaboration and competition, empowerment and direction, or routine and change (Smith and Lewis 2011, pp. 383-4). Building on this, can there be stakeholder-related organizing paradoxes that involve collaboration with competitors and/or competition with collaborators?

There is tremendous scope for cognition-related research in this domain with performance management as the focus. First, more research can be conducted with regard to the dangers (including unintended negative consequences) of simplistic business case framing (Hahn et al. 2014). Second, these dangers should be highlighted to discourage leaders from this approach to framing and encourage more paradoxical cognitive approaches like the paradox mindset (Miron- 
Spektor et al. 2018), paradoxical framing (Hahn et al. 2014) and paradoxical thinking, (Dehler et al. 2001) which is related to cognitive flexibility (Schad et al. 2016). Third, these cognitive approaches need to engaged in by not only the leaders (cf. paradoxical leadership, Smith et al. 2012) but also individuals throughout the organization (Ghadiri et al. 2015; Miron-Spektor et al. 2018). As Birkinshaw et al. (2016) point out, the success of organization design initiatives to manage paradoxes necessitates new ways of thinking and working from employees at multiple levels of the organizational hierarchy. This is echoed by Zhang, Waldman, Han, and Li (2015) who find that supervisors' holistic thinking and integrative complexity is positively related to their paradoxical behavior in managing people, which, in turn, is associated with increased proficiency, adaptivity, and proactivity among subordinates. Finally, further research could be conducted with regard to sensemaking (Jay 2013). Jay (2013) develops a process model of navigating performing paradoxes that involves sensemaking about paradoxical outcomes, and having organizational actors grapple with the definition of success and transform the organizational logic. This could result in either an oscillation among logics or a novel synthesis (Poole and Van de Ven 1989) between them when external perspectives facilitate a clearer view of the central paradox (Jay 2013).

Finally, since the work in this space appears to be more skewed towards theory papers, scholars are encouraged to correct this balance by carrying out more empirical investigations. Further, the empirical work to date has been largely qualitative (69\%) as compared to quantitative (24\%), which is understandable considering both theories are, in effect, metatheories (Ritzer 1990; Schad et al. 2016). However, this balance too could be corrected by conducting more quantitative and mixed (both qualitative and quantitative) studies in the future.

\section{Implications for practice.}


One obvious implication for practice is that paradox management competencies would become increasingly important for managers and leaders going forward. Management education has an important role to play in imparting paradoxical thinking competencies, and Audebrand et al. (2017) have already made a start in this regard. These paradoxical thinking competencies could be both general and with regard to stakeholder management in particular.

Also, the identification and articulation of the organization's core values would be particularly important. Epstein et al. (2015) speak to the importance of values when they find that one of the reasons that managers in their study were able to simultaneously manage social, environmental, and financial performance, was because their organizations' values supported long-term reasoning and decision-making. A strong organizational culture with appropriate institutionalized core values would facilitate paradox management in the creation and management of intentionally sustainable organizations (Pinto 2017).

Thus far, perhaps because it is a somewhat abstract concept, paradox has been unintentionally characterized as something extraneous and exotic. After all, organizations have been successfully led and managed over the course of history without the application of this abstract and potentially confusing 'paradox' construct. However, when framed as a means by which organizational leaders can move away from a potentially dangerous linear, short-term, and myopic approach to thinking, and toward a more holistic and balanced approach to decisionmaking that could have tremendously beneficial impact on organizational health, and consequently managerial careers, it may help make the application of paradox theory in the context of successfully managing conflicting stakeholder demands more realistic and practicable.

Smith and Lewis (2011) have attempted to delineate generic categories of organizational paradoxes, which suggests that the only paradoxes that managers and leaders have to deal with 
are those that already exist, because of the organization's operating environment and/or its governance model. However, drawing on the example of the Icehotel (Pinto 2016 and 2017), I would encourage organizational leaders to pro-actively create and enshrine paradoxes. This might seem like a way of unnecessarily inviting hard-to-deal-with complexity but as the Icehotel shows, it can work very successfully. If, like the Icehotel, the entire organization's existence is predicated on a deliberate paradox then it would be intrinsic to the organization's business model, and all stakeholders (and employees in particular) could not help but adopt a paradoxical mindset in their professional interactions. This in turn would facilitate paradox not just becoming part of the organization's core values but in fact a part of its DNA. 


\section{References}

Adler, P. S., Goldoftas, B. and Levine, D. I. (1999). Flexibility versus efficiency? A case study of model changeovers in the Toyota production system. Organization Science, 10, pp. 43-68.

Amason, A. C. (1996). Distinguishing the effects of functional and dysfunctional conflict on strategic decision making: Resolving a paradox for top management teams. Academy of Management Journal, 39, pp. 123-148.

Anagnostopoulos, C. (2014). Decision-making in English football: The case of corporate social responsibility. Unpublished doctoral dissertation, Coventry University.*

Ashforth, B. E. and Anand, V. (2003). The normalization of corruption in organizations. Research in Organizational Behavior, 25, 1-52.

Audebrand, L. K., Camus, A. and Michaud, V. (2017). A Mosquito in the Classroom: Using the Cooperative Business Model to Foster Paradoxical Thinking in Management Education. Journal of Management Education, 41, pp. 216-248.*

Ball, R. (2009). Market and Political/Regulatory Perspectives on the Recent Accounting Scandals. Journal of Accounting Research, 47, pp. 277-323.

Bansal, P. and Song, H. C. (2017). Similar but not the same: Differentiating corporate responsibility from sustainability. Academy of Management Annals, 11, doi:10.5465/annals.2015.0095.*

Bednarek, R.S. (2011). Strategizing for legitimacy in pluralistic contexts: New Zealand's Science Sector. Unpublished doctoral dissertation, Victoria University of Wellington.*

Beech, N., Burns, H., de Caestecker, L., MacIntosh, R. and MacLean, D. (2004). Paradox as invitation to act in problematic change situations. Human Relations, 57, pp. 1313-1332.

Berger, I. E., Cunningham, P. H. and Drumwright, M. E. (2007). Mainstreaming corporate social responsibility: Developing markets for virtue. California Management Review, 49, 132-157.*

Bevan, G. and Hood, C. (2006). What's measured is what matters: Targets and gaming in the English Public Health Care System. Public Administration, 84, pp. 517-538.

Bhattacharjee, Y. (2013). The mind of a con man. New York Times, Sunday Magazine, p. MM44 26 April 2013.

Birkinshaw, J., Crilly, D., Bouquet, C. and Lee, S. Y. (2016). How do firms manage strategic dualities? A process perspective. Academy of Management Discoveries, 2, pp. 51-78.*

Blavatskyy, P. R. (2005). Back to the St. Petersburg paradox? Management Science, 51, pp. 677678.

Bosch-Badia, M. T., Montllor-Serrats, J. and Tarrazon, M. A. (2013). Corporate social responsibility from Friedman to Porter and Kramer. Theoretical Economics Letters, 3, pp. 11$15 . *$

Brewer, K. (2018). Asylum decision-maker: 'It's a lottery'. BBC Stories, BBC website, 8 May 2018. 
Brownell, P. and Hirst, M. (1986). Reliance on Accounting, Information, Budgetary Participation, and Task Uncertainty: Tests of a Three-Way Interaction. Journal of Accounting Research, 24, pp. 241-249.

Buchholz R.A. and Rosenthal, S.B. (2005). Toward a contemporary conceptual framework for stakeholder theory. Journal of Business Ethics, 58, pp. 137-148.*

Calton, J.M. and Payne, S.L. 2003. Coping with paradox: Multistakeholder learning dialogue as a pluralist sensemaking process for addressing messy problems. Business \& Society, 42, pp. 742.*

Cheruiyot, T.K. and Maru, L.C. (2012). Employee social responsibility practices and outcomes in Kenya's tourist hotels. African Journal of Economic and Management Studies, 3, pp. 2341.*

Clark, C.E., Steckler, E.L. and Newell, S., 2016. Managing contradiction: Stockholder and a stakeholder views of the firm as paradoxical opportunity. Business and Society Review, 121, pp.123-159.*

Clegg, R.S., Da Cunha, V. and e Cunha, P.M. (2002). Management paradoxes: A relation view. Human Relations, 55, pp. 483-503.

Collins, D. and Zheng, C. (2015). Managing the poverty-CO2 reductions paradox: The case of China and the EU. Organization \& Environment, 28, pp. 355-373.*

Cornforth, C. (2004). The governance of cooperatives and mutual associations: A paradox perspective. Annals of Public and Cooperative Economics, 75, pp. 11-32.*

Coval, J., Jurek, J. and Stafford, E. (200). The economics of structured finance. Journal of Economic Perspectives, 23, pp. 3-25.

Cronbach, L.J. and Meehl, P.E. (1955). Construct validity in psychological tests. Psychological Bulleting, 52, pp. 281-302.

Crotty, J. (2009). Structural causes of the global financial crisis: A critical assessment of the 'new financial architecture'. Cambridge Journal of Economics, 33, pp. 563-580.

Dahlmann, F. (2016). Organisational fitness searches in the Anthropocene: integrating paradox and corporate sustainability. Unpublished working paper. Coventry: Warwick Business School.*

De Cuyper, N. and De Witte, H. (2011). The management paradox: Self-rated employability and organizational commitment and performance. Personnel Review, 40, pp. 152-172.

Dehler, G.E., Welsh, A. and Lewis, M.W. (2001). Critical pedagogy in the "new paradigm". Management Learning, 32, pp. 493-511.

Demb, A. and Neubauer, F.F. (1992). The corporate board: Confronting the paradoxes. Long Range Planning, 25, pp. 9-20.

Dempsey, M. (2004). Managing trade unions: A case study examination of managerial activities in four UK trade unions formed by merger. Unpublished doctoral dissertation, Cranfield University.*

Denis, J. L., Langley, A. and Sergi, V. (2012). Leadership in the plural. Academy of Management Annals, 6, pp. 211-283. 
De Prins, P., De Vos, A., Van Beirendonck, L. and Segers, J. (2015). Sustainable HRM for sustainable careers: Introducing the 'Respect Openness Continuity (ROC) model'. Handbook of Research on Sustainble Careers, pp. 319-334.*

De Rond, M., \& Miller, A. N. (2005). Publish or perish: bane or boon of academic life?. Journal of Management Inquiry, 14(4), 321-329.

Dodd, D., \& Favaro, K. (2006). Managing the right tension. Harvard Business Review, 84, pp. 62-74.

Donaldson, T. and Preston, L. E. (1995). The stakeholder theory of the corporation: Concepts, evidence, and implications. Academy of Management Review, 20, pp. 65-91.

Doty, D.H. and Glick, W.H. (1994). Typologies as a unique form of theory building: Toward improved understanding and modeling. Academy of Management Review, 19, pp. 230-251.

Drucker, P. F. (1954). The practice of management: A study of the most important function in America society. Harper \& Brothers.

Dubin, R. (1969). Theory building. New York: Free Press.

Ebrahim, A., Battilana, J. and Mair, J. (2014). The governance of social enterprises: Mission drift and accountability challenges in hybrid organizations. Research in Organizational Behavior, 34, pp. 81-100.

Ehnert I. 2009. Sustainable Human Resource Management: A Conceptual and Exploratory Analysis from a Paradox Perspective. Heidelberg: Physica-Verlag.

Ehnert, I. and Harry, W. (2012). Recent developments and future prospects on sustainable human resource management: introduction to the special issue. Management Revue, 23, pp. 221238.*

Ehnert, I., Parsa, S., Roper, I., Wagner, M. and Muller-Camen, M. (2016). Reporting on sustainability and HRM: A comparative study of sustainability reporting practices by the world's largest companies. The International Journal of Human Resource Management, 27, pp. 88-108.*

Epstein, M. J., Buhovac, A. R. and Yuthas, K. (2015). Managing social, environmental and financial performance simultaneously. Long Range Planning, 48, pp. 35-45.*

Fiegenbaum, A. and Thomas, H. (1988). Attitudes toward risk and the risk-return paradox: prospect theory explanations. Academy of Management Journal, 31, pp. 85-106.

Freeman, R.E. (1984). Strategic management: A stakeholder approach. Englewood Cliffs, NJ: Prentice-Hall.

Freeman, R.E. (1994). The politics of stakeholder theory: Some future directions. Business Ethics Quarterly, 4, pp. 409-421.

Freeman, R.E. and McVea, J. 2001. A stakeholder approach to strategic management. In M.A. Hitt, R.E. Freeman, \& J.S. Harrison (Eds.), The Blackwell Handbook of Strategic Management, pp. 189-207. Oxford: Blackwell.

Freeman, R.E. and Reed, D.L. (1983) Stockholders and stakeholders: A new perspective on corporate governance. California Management Review, 25, pp.88-106.* 
Freeman, R.E. (2010). Strategic management: A stakeholder approach. Cambridge University Press.*

Freeman, R.E., Wicks, A.C. and Parmar, B.L. (2004). Stakeholder theory and "The corporate objective revisited". Organization Science, 15, pp. 364-369.

Froese, A. (2017). Organizations in balance: revitalizing the concept of organizational equilibrium. uwf UmweltWirtschaftsForum, pp.1-9.*

Galuppo, L., Gorli, M., Scaratti, G. and Kaneklin, C. (2014). Building social sustainability: multi-stakeholder processes and conflict management. Social Responsibility Journal, 10, pp. 685-701.*

Gao, J. and Bansal, P. (2013). Instrumental and integrative logics in business sustainability. Journal of Business Ethics, 112, pp. 241-255.*

Gergen, K. (1992). Organization theory in the postmodern era. In M. Reed and M. Hughes (Eds.) Rethinking Organization. London: Sage, pp. 207-226.

Ghadiri, D. P., Gond, J. P. and Brès, L. (2015). Identity work of corporate social responsibility consultants: Managing discursively the tensions between profit and social responsibility. Discourse \& Communication, 9, pp. 593-624.*

Goodpaster, K. (1991). Business ethics and stakeholder analysis. Business Ethics Quarterly, 1, pp. 53-73.

Gould, R.W. (2012). Open innovation and stakeholder engagement. Journal of Technology Management \& Innovation, 7, pp. 1-11.*

Grizzle, G.A. (2002). Performance measurement and dysfunction: The dark side of quantifying work. Public Performance \& Management Review, 25, pp. 363-369.

Guerci, M. and Pedrini, M. (2014). The consensus between Italian HR and sustainability managers on HR management for sustainability-driven change - towards a 'strong' HR management system. The International Journal of Human Resource Management, 25, pp. 1787-1814.

Gurtner, S. and Reinhardt, R. (2016). Ambidextrous idea generation - Antecedents and Outcomes. Journal of Product Innovation and Management, 33, pp. 34-54.*

Haffar, M. and Searcy, C. (2017). Classification of trade-offs encountered in the practice of corporate sustainability. Journal of Business Ethics, 140, pp. 495-522.*

Hahn, T., Figge, F., Pinkse, J. and Preuss, L. (2017). A paradox perspective on corporate sustainability: descriptive, instrumental, and normative aspects. Journal of Business Ethics, pp. 1-14.*

Hahn, T., Pinkse, J., Preuss, L. and Figge, F. (2015). Tensions in corporate sustainability: Towards an integrative framework. Journal of Business Ethics, 127, pp. 297-316.*

Hahn, T., Preuss, L., Pinkse, J. and Figge, F. (2014). Cognitive frames in corporate sustainability: Managerial sensemaking with paradoxical and business case frames. Academy of Management Review, 39, pp. 463-487.*

Handy, C. B. (1995). The age of paradox. Harvard Business Press. 
Hannan, R. (2014). The institution of co-operation: A pathway from governance to spillover and poverty reduction. Journal of Co-operative Organization and Management, 2, pp. 34-42.*

Hargrave, T. J. and Van de Ven, A. H. (2017). Integrating dialectical and paradox perspectives on managing contradictions in organizations. Organization Studies, 38, pp. 319-339.*

Harris, K. and Metcalfe, M. (2015). Using Consequence Networking to Identify Paradox. Systems Research and Behavioral Science, 32, pp. 64-74.*

Harvey, J. B. (1988). The Abilene paradox: The management of agreement. Organizational Dynamics, 17, pp. 17-43.

Heath, J. and Norman, W. (2004). Stakeholder theory, corporate governance and public management: What can history of state-run enterprises teach us in the post-Enron era? Journal of Business Ethics, 53, pp. 247-265.

Hemme, F. (2017). Change in a public-recreation organization: A multiple-case study. Unpublished doctoral dissertation, University of Texas at Austin.*

Hershcovis, M. S. (2011). “Incivility, social undermining, bullying... oh my!": A call to reconcile constructs within workplace aggression research. Journal of Organizational Behavior, 32, pp. 499-519.

Heydenreich, A.K. (2008). Organising a multi-stakeholder process: Creating a paradoxical collaborative identity. Unpublished doctoral dissertation, University of St. Gallen.*

Hillebrand, B., Driessen, P. H. and Koll, O. (2015). Stakeholder marketing: Theoretical foundations and required capabilities. Journal of the Academy of Marketing Science, 43, pp. 411-428.*

Hitchen, L. (2007). Robbing Peter to pay Paul. BMJ: British Medical Journal, 334, p. 388.

Hoffmann, J. (2018). Talking into (non)existence: Denying or constituting paradoxes of Corporate Social Responsibility. Human Relations, 71, pp. 668-691.*

Hough, A., McGregor-Lowndes, M. and Ryan, C. M. (2005). Theorizing about board governance of nonprofit organizations: Surveying the landscape. In $34^{\text {th }}$ Annual Conference of the Association for Research on Nonprofit Organizations and Voluntary Action, 17-19 November 2005, Washington DC (Unpublished).*

Huy, Q. N. (2002). Emotional balancing of organizational continuity and radical change: The contribution of middle managers. Administrative Science Quarterly, 47, pp. 31-69.

Jamali, D. (2008). A stakeholder approach to corporate social responsibility: A fresh perspective into theory and practice. Journal of Business Ethics, 82, pp. 213-31.

Jansson, N. (2015). Permanent tensions in organization: An obstacle or an opportunity for the change discourse? Journal of Health Organization and Management, 29, pp. 654-669.*

Jarzabkowski, P., Lê, J. and Van de Ven, A. (2013). Responding to competing strategic demands: How organizing, belonging, and performing paradoxes coevolve. Strategic Organization, 11, pp. 245-280.

Jay, J. (2013). Navigating paradox as a mechanism of change and innovation in hybrid organizations. Academy of Management Journal, 56, pp. 137-159.* 
Jensen, M.C. (2001). Value Maximisation, Stakeholder Theory, and the Corporate Objective Function. European Financial Management, 7, pp. 297-317.

Kaplan, R.S. and Norton, D.P. (1996). The Balanced Scorecard-Translating Strategy into Action. Boston, MA: Harvard Busines School Press.

Kannothra, C. G., Manning, S. and Haigh, N. (2017). How Hybrids Manage Growth and SocialBusiness Tensions in Global Supply Chains: The Case of Impact Sourcing. Journal of Business Ethics, pp. 1-20.*

Kornum, N. (2007). Company stakeholder responsibility: A resource-based perspective. Unpublished working paper, Department of Marketing, Copenhagen Business School.*

Kozica, A., \& Kaiser, S. (2012). A sustainability perspective on flexible HRM: How to cope with paradoxes of contingent work. Management Revue, pp. 239-261.

Kraatz, M. and Block, E. (2008). Organizational implications of institutional pluralism. In R. Greenwood, C. Oliver, R. Suddaby, \& K. Sahlin-Andersson (Eds.), The Sage Handbook of Organizational Institutionalism, Thousand Oaks, CA: Sage, pp. 243-275.

Kumeto, G. (2015). Behavioral Agency Theory and the Family Business. Theoretical Perspectives on Family Businesses, pp. 78-98.*

Lapointe, L., Mignerat, M. and Vedel, I. (2011). The IT productivity paradox in health: A stakeholder's perspective. International Journal of Medical Informatics, 80, pp. 102-115.

Langfred, C. W. (2000). The paradox of self-management: Individual and group autonomy in work groups. Journal of Organizational Behavior, 21, pp. 563-585.

Lankoski, L. and Smith, N. C. (2017). Alternative Objective Functions for Firms. Organization \& Environment, pp. 1-21.*

Leonard-Barton, D. (1992). Core capabilities and core rigidities: A paradox in managing new product development. Strategic Management Journal, 13, pp. 111-125.

Lewis, M.W. (2000). Exploring paradox: Toward a more comprehensive guide. Academy of Management Review, 25, pp. 760-776.

Lewis, M.W. and Smith, W.K. (2014). Paradox as a metatheoretical perspective: Sharpening the focus and widening the scope. The Journal of Applied Behavioral Science, 50, pp. 127-149.

Llewellyn, D.G. (2007). The role and influence of the secretary in relation to governing bodies in higher education. Unpublished doctoral dissertation, University of Bath.*

Lim, C. Y., Woods, M., Humphrey, C. and Seow, J. L. (2017). The paradoxes of risk management in the banking sector. The British Accounting Review, 49, pp. 75-90.*

Lüscher, L. S. and Lewis, M. W. (2008). Organizational change and managerial sensemaking: Working through paradox. Academy of Management Journal, 51, pp. 221-240.

Marcon, G. and Dorigo, L. (2012). Stakeholder theory and care management: An inquiry into social enterprises. University of Venice, Department of Management, Working Paper Series.

Mason, C. and Doherty, B. (2016). A fair trade-off? Paradoxes in the governance of fair-trade social enterprises. Journal of Business Ethics, 136, pp.451-469.* 
Mayers, N. (2016). Bringing them together: Integrating economic and social-ecological dimensions in corporate decision-making. Unpublished doctoral dissertation, University of Cape Town.*

McMullen, J.S. and Bergman, B. (2017). Social Entrepreneurship and The Development Paradox of Prosocial Motivation: A Cautionary Tale. Strategic Entrepreneurship Journal, 11, pp. 243$270 *^{*}$

Mersland, R. (2009). The cost of ownership in microfinance organizations. World Development, 37, pp. 469-478.*

Miller, A. N., Taylor, S. G., \& Bedeian, A. G. (2011). Publish or perish: academic life as management faculty live it. Career Development International, 16, pp. 422-445.

Minoja, M. (2012). Stakeholder management theory, firm strategy, and ambidexterity. Journal of Business Ethics, 109, pp. 67-82.

Miron-Spektor, E., Ingram, A., Keller, J., Smith, W. and Lewis, M. (2018). Microfoundations of organizational paradox: The problem is how we think about the problem. Academy of Management Journal, 61, pp. 26-45.*

Mitchell, R.K., Agle, B.R. and Wood, D.J. (1997). Toward a theory of stakeholder identification and salience: Defining the principle of who and what really counts. Academy of Management Review, 22, pp. 853-886.

Nixon, B. and Burns, J. (2012). The paradox of strategic management accounting. Management Accounting Research, 23, pp. 229-244.

Ocasio, W. (1997). Towards an attention-based view of the firm. Strategic Management Journal, 18, pp. 187-206.

Ocasio, W. and Radoynovska, N. (2016). Strategy and commitments to institutional logics: Organizational heterogeneity in business models and governance. Strategic Organization, 14, pp. 287-309.*

Odiorne, G. S. (1965). Management by objectives: A system of managerial leadership. New York: Pitman Pub. Corp.

Pache, A. C. and Santos, F. (2010). When worlds collide: The internal dynamics of organizational responses to conflicting institutional demands. Academy of Management Review, 35, pp. 455-476.

Pache, A. C. and Santos, F. (2013). Inside the hybrid organization: Selective coupling as a response to competing institutional logics. Academy of Management Journal, 56, pp. 9721001.

Parmar, B. L., Freeman, R. E., Harrison, J. S., Wicks, A. C., Purnell, L. and de Colle, S. (2010). Stakeholder theory: The state of the art. Academy of Management Annals, 4, pp. 403-445.

Parr, C. (2014). Imperial College professor Stefan Grimm 'was given grant income target'. Times Higher Education website, December 3 ${ }^{\text {rd }}, 2014$.

Phillips, R., Freeman, R.E. and Wicks, A.C. (2003). What stakeholder theory is not. Business Ethics Quarterly, 13, pp. 479-502. 
Pinto, J. (2016). 'Wow! That's so cool!' The Icehotel as organizational trope. Human Relations, 69, pp. 891-914.*

Pinto, J. (2017). A multifocal framework for developing Intentionally Sustainable Organizations Current Opinion in Environment Sustainability, 28, pp. 17-23.*

Pinto, J., Leana, C. R. and Pil, F. K. (2008). Corrupt organizations or organizations of corrupt individuals? Two types of organization-level corruption. Academy of Management Review, 33, pp. 685-709.

Poole, M. S. and Van de Ven, A. H. (1989). Using paradox to build management and organization theories. Academy of Management Review, 14, pp. 562-578.

Retraction Watch (2012). Three papers by German management professor retracted for duplication, statistical issues. Retraction Watch Blog, July 17'2012.

Retraction Watch (2014). After 16 retractions management professor Lichtenthaler resigns post. Retraction Watch Blog, October 10, 2014.

Radnor, Z. (2008). Muddled, massaging, manoeuvring or manipulated? A typology of organisational gaming. International Journal of Productivity and Performance Management, 57, pp. 316-328.

Ricks, J. and Fraedrich, J. (1999). The paradox of Machiavellianism: Machiavellianism may make for productive sales but poor management reviews. Journal of Business Ethics, 20, pp. 197-205.

Ritzer, G. (1990). Metatheorizing in sociology. Sociological Forum, 5, pp. 3-15.*

Rouse, J. (1993). Resource and performance management in public service organizations. In Kester, I., Painter C. and Barnes, C. (Eds.) Management in the Public Sector. London: Chapman and Hall.

Savaneviciene, A. and Stankeviciute, Z. (2014). The disclosure of sustainability and Human Resource Management linkage. Human Resources Management \& Ergonomics, 8, pp. 88104.*

Schad, J., Lewis, M.W., Raisch, S. and Smith, W.K. (2016). Paradox research in management science: Looking back to move forward. The Academy of Management Annals, 10, pp. 5-64.*

Scherer, A. G., Palazzo, G. and Seidl, D. (2013). Managing legitimacy in complex and heterogeneous environments: Sustainable development in a globalized world. Journal of Management Studies, 50, 259-284.*

Schneider, D. M. and Goldwasser, C. (1998). Be a model leader of change. Management Review, 87, pp. 41-45.

Shadish, W.R., Cook, T.D. and Campbell, D.T. (2002). Experimental and quasi-experimental designs for generalized causal inference. Boston: Houghton Mifflin.

Shaffer, J. A., DeGeest, D. and Li, A. (2016). Tackling the problem of construct proliferation: A guide to assessing the discriminant validity of conceptually related constructs. Organizational Research Methods, 19, pp. 80-110.

Slawinski, N. and Bansal, P. (2015). Short on time: Intertemporal tensions in business sustainability. Organization Science, 26, pp. 531-549.* 
Smith, P. (1993). Outcome-related Performance Indicators and Organizational Control in the Public Sector. British Journal of Management, 4, pp. 135-151.

Smith P. (1995). On the unintended consequences of publishing performance data in the public sector. International Journal of Public Administration, 18, pp. 288-310.

Smith, W. K. (2014). Dynamic decision making: A model of senior leaders managing strategic paradoxes. Academy of Management Journal, 57, pp. 1592-1623.*

Smith, W. K., Besharov, M. L., Wessels, A. K. and Chertok, M. (2012). A paradoxical leadership model for social entrepreneurs: Challenges, leadership skills, and pedagogical tools for managing social and commercial demands. Academy of Management Learning \& Education, 11, pp. 463-478.*

Smith, W. K., Gonin, M. and Besharov, M. L. (2013). Managing social-business tensions: A review and research agenda for social enterprise. Business Ethics Quarterly, 23, pp. 407-442.*

Smith, W.K. and Lewis, M.W. (2011). Toward a theory of paradox: A dynamic equilibrium model of organizing. Academy of Management Review, 36, pp. 381-403.*

Smith, W.K. and Tracey, P. (2016). Institutional complexity and paradox theory: Complementarities of competing demands. Strategic Organization, 14, pp. 455-466.*

Spiller, R. (2000). Ethical business and investment: A model for business and scoiety. Journal of Business Ethics, 27, pp. 149-160.

Sternberg, E. (1997). The defects of stakeholder theory. Corporate Governance: An International Review, 5, pp. 3-10.

Tornau, K. and Frese, M. (2013). Construct clean-up in proactivity research: A meta-analysis on the nomological net of work-related proactivity concepts and their incremental validities. Applied Psychology: An International Review, 62, pp. 44-96.

Van der Byl, C. A. and Slawinski, N. (2015). Embracing tensions in corporate sustainability: A review of research from win-wins and trade-offs to paradoxes and beyond. Organization \& Environment, 28, pp. 54-79.*

Vangen, S. (2017). Developing Practice-Oriented Theory on collaboration: A paradox lens. Public Administration Review, 77, pp. 263-272.*

Van Marrewijk, M. (2003). Concepts and definitions of CSR and corporate sustainability: Between agency and communion. Journal of Business Ethics, 44, pp. 95-105.

Vilanova, M., Lozano, J.M. and Arenas, D. (2009). Exploring the nature of the relationship between CSR and competitiveness. Journal of Business Ethics, 87, pp. 57-69.*

West, A. (2006). Theorising South Africa's corporate governance. Journal of Business Ethics, 68, pp. 433-448.*

Wheeler, D., Fabig, H., and Boele, R. (2002). Paradoxes and dilemmas for stakeholder responsive firms in the extractive sector: Lessons from the case of Shell and the Ogoni. Journal of Business Ethics, 39, pp. 297-318.*

Wijen, F., \& Ansari, S. (2007). Overcoming inaction through collective institutional entrepreneurship: Insights from regime theory. Organization Studies, 28, pp. 1079-1100. 
Wright, P. M., Dunford, B. B., \& Snell, S. A. (2001). Human resources and the resource based view of the firm. Journal of Management, 27, pp. 701-721.

Wright, P. M., \& Snell, S. A. (1998). Toward a unifying framework for exploring fit and flexibility in strategic human resource management. Academy of Management Review, 23, pp. 756-772.

Zaugg, R. (2009). Nachhaltiges Personalmanagement: Eine neue Perspektive und empirische Exploration des Human Resource Management. Springer.

Zhang, Y., Waldman, D. A., Han, Y. L., and Li, X. B. (2015). Paradoxical leader behaviors in people management: Antecedents and consequences. Academy of Management Journal, 58, pp. 538-566. 